\title{
HYDROXYKYNURENINURIA
}

\section{A CASE OF ABNORMAL TRYPTOPHAN METABOLISM PROBABLY DUE TO A DEFICIENCY OF KYNURENINASE}

\author{
BY \\ G. M. KOMROWER, VERA WILSON, J. R. CLAMP and R. G. WESTALL \\ From the Research Unit, Royal Manchester Children's Hospital, and \\ Medical Unit, University College Hospital Medical School, London
}

(RECEIVED FOR PUBLICATION JANUARY 14, 1964)

During the past decade the route by which tryptophan is converted to nicotinamide has been well studied, but the later stages of the conversion have yet to be fully explained. This tryptophannicotinamide transformation has been shown to occur in mammals (Rosen, Huff and Perlzweig, 1946) and later the formation of labelled nicotinic acid from $\mathrm{C}^{14}$-labelled tryptophan was demonstrated by Heidelberger, Abraham and Leprovsky (1949). Kotake and Nakayama (1941) and Dalgliesh, Knox and Neuberger (1951) showed that, along this series of reactions, the conversion of kynurenine to anthranilic acid and of 3-hydroxykynurenine to 3-hydroxyanthranilic acid was, in each instance, catalysed by the same enzyme, namely kynureninase. Charconnet-Harding, Dalgliesh and Neuberger (1953) found that in addition to kynurenine, kynurenic acid and xanthurenic acid, 3-hydroxykynurenine was excreted on administration of tryptophan to rats fed on a low pyridoxin diet.

Many workers since have demonstrated these tryptophan derivatives in the urines of pyridoxyldeficient or pyridoxyl-dependent individuals (Bessey, Adam and Hansen, 1957; Molony and Parmelee, 1954; Coursin, 1961; Hunt, Stokes, McCrory and Stroud, 1954; Scriver, 1960; O'Brien and Jensen, 1963) usually following a tryptophan load. In addition xanthurenic acid has been found in the urine of uncontrolled diabetics (Kotake and Tani, 1953) and in tropical sprue (Sigler, Sheehy, Santini and Rubini, 1962) and 3-hydroxykynurenine in cases of active tuberculosis, fever of various kinds and in leukaemia, multiple myeloma lymphosarcoma and Hodgkin's disease (Musajo, Benassi and Parpajola, 1956). Further, Knapp (1962) has reported that a number of patients excrete an increased amount of these tryptophan metabolites after tryptophan load tests. This was not due to pyridoxin deficiency, and he concluded that this was an inherited trait. However, there has been no report concerning the presence of large amounts of these substances in the urines of subjects without active disease who have an adequate pyridoxin intake under normal dietary conditions. We describe here an individual who seems to show this abnormality.

\section{Case History}

R.R., the first and only child, was born at term on July 3, 1952 following a normal pregnancy. The birth weight was $7 \mathrm{lb} .8 \mathrm{oz}$. (3402 g.), and following a breech extraction the baby was shocked and anoxic. However, she responded quickly to oxygen therapy, fed well and regained her birth weight by the eighth day. She was noted to be short (length $17 \frac{1}{2}$ in. $(44 \mathrm{~cm}$.), but radiological examination of the skeleton was said to be normal. She was discharged home and readmitted after 14 days because of, (i) reddening of the buttocks with some desquamation; (ii) mild stomatitis and gingivitis; and (iii) loose stools with occasional flecks of blood.

On examination she weighed $7 \mathrm{lb} .8 \mathrm{oz}$. (3402 g.) and was pyrexial. There was marked stomatitis and cervical adenitis. Buttocks were reddened. She was pale. Full blood count revealed red blood cells $2 \cdot 58$ million. $\mathrm{Hb} 7 \cdot 7 \mathrm{~g} . / 100 \mathrm{ml}$., colour index $1 \cdot 06$, white blood cells 3,800 per c.mm., neutrophils $27 \%$, eosinophils $8 \%$, lymphocytes $59 \%$, monocytes $6 \%$. Blood Group B, Rhesus negative. Coombs test, negative.

Treatment was started with chlortetracycline, vitamin $\mathrm{C}$ and 'becosym'. The state of the mouth and buttocks improved but the child remained pyrexial and anaemic. Hepatosplenomegaly was not noted. On August 7, 1952 she was transferred to Royal Manchester Children's Hospital. Her weight was 7 lb. 9 oz. (3430 g.); temperature $102^{\circ} \quad \mathrm{F} . \quad\left(39^{\circ}\right.$ C. $)$. There was marked stomatitis, and the buttocks were reddened, with some excoriation. The liver and spleen were felt 1 in. $(2 \cdot 5 \mathrm{~cm}$.) below the respective costal margins. There was a slight 
kyphoscoliosis, and shortness of the upper arms and thighs relative to the size of the trunk and rest of the limbs was noted.

Investigations. $\mathrm{Hb} \quad 44 \% \quad(6.5 \quad \mathrm{~g} . / 100 \mathrm{ml}$.$) , white$ blood cells 9,200 , polymorphs $13 \%$, lymphocytes $74 \%$, eosinophils $7 \%$, monocytes $5 \%$, reticulocytes $1 \%$; Coombs, direct and indirect, negative; some increase of fragility, $25 \%$ haemolysis at $0.6 \mathrm{~N}$ saline. Iliac crest marrow showed a picture of marked normoblastic hyperplasia. Urobilin was present in slight excess. Liver function tests showed no evidence of parenchymal cell disturbance.

This was thought to be an acquired haemolytic anaemia, as the Coombs test on two further occasions was positive, and $100 \mathrm{ml}$. of compatible blood was given. Marked accentuation of jaundice was noted with an increase of the hepatosplenomegaly following the transfusion.

The pyrexia was maintained and after one week the stools became very frequent and the anaemia more pronounced.

On August 16, 1952, a further transfusion was given; once again there was an increase of jaundice with some further enlargement of the liver.

Glucose in quantity and vitamin B complex were given as therapy. Two days later a left otorrhoea was noted and appropriate parenteral and local antibiotic therapy was started. From this point the jaundice began to fade but the hepatosplenomegaly persisted. The diarrhoea was still present, and there was an obvious proctitis. The ear condition began to clear but on September 7, an appreciable amount of pus was passed per rectum followed later by some blood.

Following a further transfusion the anaemia improved, the hepatosplenomegaly diminished, the left ear became dry, but blood and pus continued to be passed per rectum. Esch. coli and Staph. albus were grown from the rectal swab. . On radiological investigation barium enema and barium meal examinations did not reveal any abnormalities of the intestine or colon, but developmental defects of the lower dorsal and first lumbar vertebrae and of the eighth, ninth, eleventh and twelfth left ribs were noted. The long bones were seen to be short and the development of the left leg epiphysial centres somewhat in advance of the right. A diagnosis of 'Brailsford-Morquio' was suggested.

In October a laparotomy was performed when the pelvic colon was found to be inflamed. Chloramphenicol $100 \mathrm{mg}$. eight-hourly was given for 15 days, and local chinioform enemata were started and continued for two months. The fever settled slowly, the diarrhoea abated, the proctitis and peri-anal redness improved. The blood count on December 17 was red blood cells 3.8 million; Hb $72 \%$; white blood cells 9,400: polymorphs $45 \%$; lymphocytes $42 \%$; monocytes $9 \%$.

Repeated blood cultures taken during the illness had been negative and a mesenteric gland taken at biopsy did not reveal any particular pathology.

On December 24 she was discharged from hospital. Her diet consisted of 'Trufood,' a protein hydrolysate preparation, 'Prosol', cereal and a vitamin preparation, 'Abidec'.

During 1953 she made slow but steady progress. The liver and spleen diminished in size and could no longer be felt, although on re-examination the right femoral caput epiphysis was still less well developed than the left.

All the milestones were reached late, and in July 1956 at the age of 4 years her vocabulary was poor, although she understood everything that was said to her. She had just begun to play with other children, and bowel and bladder training were satisfactory.

She continued to progress with adequate radiological ossification of the head of the right femur, and she was next seen in July 1960 at the age of 8 years 2 months when she was brought because the school authorities said she was mentally retarded. On examination her general condition was good, there was no shortening of the right leg, but there was a conductive deafness in the left ear. The I.Q. was 78 (verbal scale I.Q. 96: performance scale I.Q. 64). Further radiological examination showed a definite improvement in the outline and internal bony structure of the head and neck of the right femur. Development as to size and number of carpal centres was above the average (centre for pisiform forming).

Detailed investigations were undertaken and will be described later.

In September 1962 at the age of 10 years 2 months nicotinic acid ('niacin') $10 \mathrm{mg}$. was prescribed in addition to pyridoxin $50 \mathrm{mg}$. daily.

In November 1963 at 11 years 4 months she was in excellent health, having made an appreciable gain in height and weight (Fig. 1) during the previous 18 months. She was heavily built and secondary sexual characteristics were appearing (Fig. 2). The progress at school had been good although she was still one year behind her age-group. She had suffered from migrainous headaches before the introduction of nicotinic acid therapy; since that time she had had only one headache, when the vitamins had been omitted for four days. Her mother and grandmother both suffered in a similar manner although her mother had been very well following the introduction of daily 'Becosym forte' (pyridoxin $20 \mathrm{mg}$.; niacin $100 \mathrm{mg}$.). As the red cell fragility had been abnormal in infancy this investigation was repeated; this had returned to normal.

\section{Methods}

Urine Collection. Aliquots of 24-hour collections were used for analysis except after the tryptophan loading tests when four consecutive three-hourly specimens were obtained followed by a final collection between 12 and 24 hours.

Paper Chromatography. Two-way paper chromatograms of the urinary tryptophan derivatives were done by following the method of Smith (1958) using n-butanol, acetic acid and water $(120 ; 30 ; 50$ parts by volume $)$ as the first solvent and $20 \%$ potassium chloride as second solvent. The position of the substances was ascertained by viewing the papers under ultraviolet light $(253 \mathrm{~m} \mu)$. Approximate assessments of the amounts of kynurenine, 


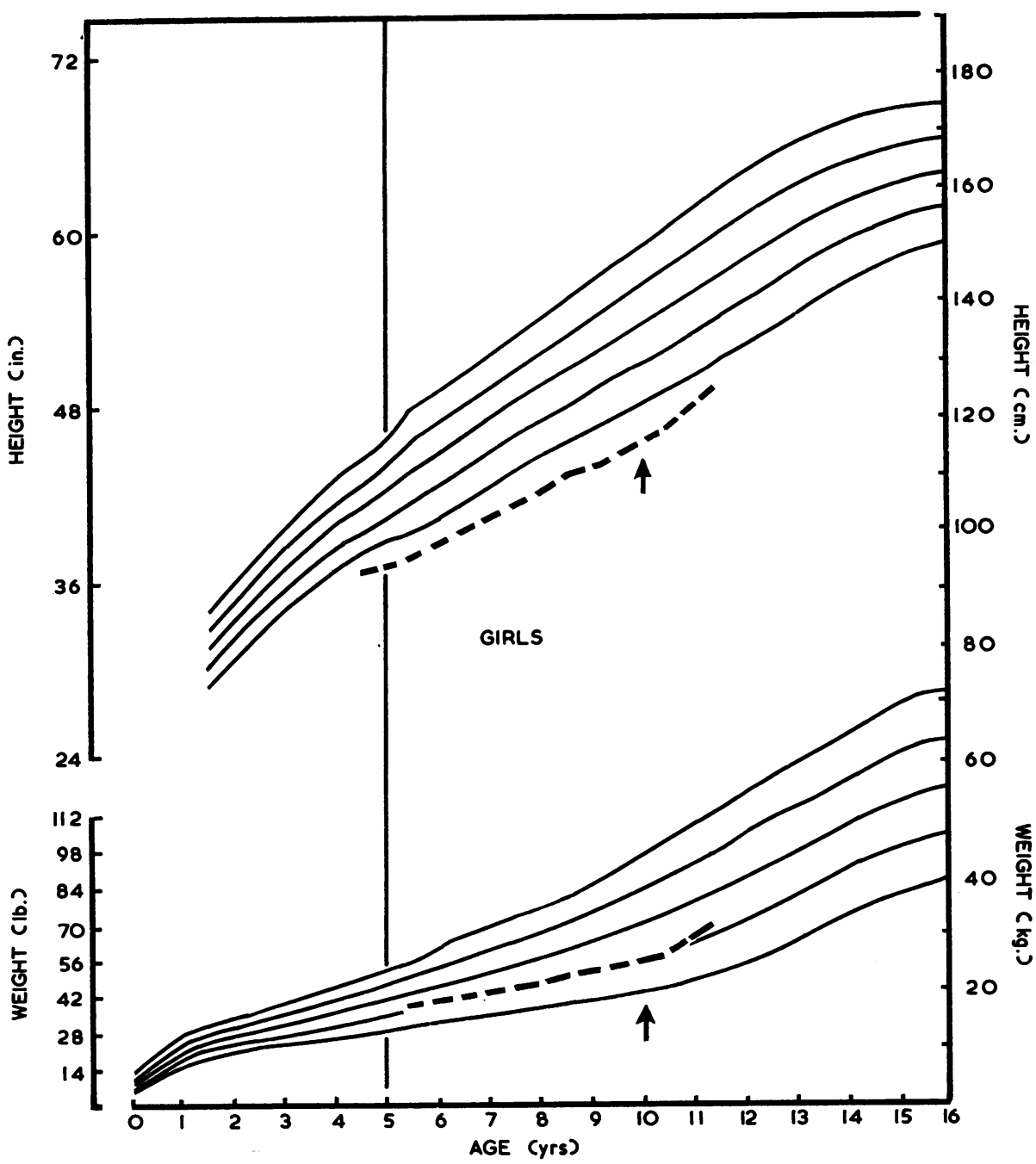

Fig. 1.-Height and weight chart of patient. Arrow indicates point of introduction of pyridoxin $50 \mathrm{mg}$. and nicotinic acid $10 \mathrm{mg}$. daily.

3-hydroxykynurenine and kynurenic acid were made by matching with spots on the chromatograms given by standard amounts of the authentic substances run simultaneously.

Xanthurenic Acid. Quantitative determinations of xanthurenic acid were made by spectrophotometric measurement of the colour given with ferric ammonium sulphate (Wachstein and Gudaitis, 1952).

In addition, high-voltage paper electrophoresis (Smith, 1960) was used as a further check on the identity of the urinary tryptophan metabolites.

\section{Results}

Routine investigations of the urine of the patient for protein, calcium, glucose, cystine and keto-acids were normal but a greenish-brown colour was given with ferric chloride. It was also noted that the urine darkened in colour over a period of days when stored at $2^{\circ} \mathrm{C}$. The amino acid paper chromatogram (Dent, 1951) of the patient's urine showed no appreciable aminoaciduria, but there was a brownishcoloured spot near the valine position on the untreated square, which turned greyish-purple after spraying with ninhydrin: this spot was later identified as 3-hydroxykynurenine. When the urine from the patient was examined by paper chromatography using the two-way system, butanol-acetic acid-water, and $20 \% \mathrm{KCl}$, at least six well-defined spots could be seen when the paper was viewed under ultraviolet 
light. A typical paper chromatogram is reproduced in diagrammatic form in Fig. 3. By means of published $\mathbf{R}_{\mathbf{F}}$ values in this and other solvent systems and from comparison with the behaviour of known marker substances these six spots have been tentatively identified. The two most conspicuous spots are due to (1) xanthurenic acid and (2) 3hydroxykynurenine. Spot (3) is 3-hydroxykynurenine sulphate, (4) kynurenine, (5) kynurenic acid and (6) is a conjugated form of xanthurenic acid $\beta$-(8xanthurenyl)-glucosiduronic acid (Johnston and Mason, 1962). When urine samples from normal people are run under similar conditions and the chromatograms are examined in ultraviolet light these fluorescent spots are not usually seen although occasionally one can observe a weak spot due to kynurenine. However, if the normal subject is given an oral load of L-tryptophan $(70 \mathrm{mg} . / \mathrm{kg}$.) and the urine passed during the following 12 hours is examined by paper chromatography then all the six substances cited above are present in the urine in sufficiently high concentration to give distinct spots on the paper. In fact two further spots are discernible, which are due to the presence of the acetylated derivatives of kynurenine and 3-hydroxykynurenine (Dalgliesh, 1956). The amounts of these metabolites excreted under the influence of a tryptophan load vary only slightly from individual to individual, but under our conditions there is a difference with age in the amount of xanthurenic acid excreted. Children with adequate dietary sources of pyridoxin rarely excrete more than $1-2 \mu \mathrm{M} / \mathrm{kg}$./day of xanthurenic acid during the 24-hour urine collection period while many normal adults will excrete $5-7 \mu \mathrm{M} / \mathrm{kg}$./ day of this substance (Table 1).

Individuals with a deficiency of or an increased requirement for pyridoxin excrete large amounts of xanthurenic acid in the urine after an oral load of tryptophan, and as the patient did this without any such stress she was given maintenance doses of $50 \mathrm{mg}$. and later $100 \mathrm{mg}$. pyridoxin daily for several weeks. This supplementation failed to change the pattern of or appreciably alter the relative amounts of the tryptophan metabolites in the urine. Nor was the pattern altered by a period on a vegetablefree diet or by additional supplements of ascorbic acid.

Quantitative assessments of these tryptophan metabolites in the urine of the patient when on a normal diet are as follows:-xanthurenic acid, 21 $\mu \mathrm{M} / \mathrm{kg}$./day; 3-hydroxykynurenine, $25 \mu \mathrm{M} / \mathrm{kg}$./day; kynurenine, $3.5 \mu \mathrm{M} / \mathrm{kg}$./day and kynurenic acid, $5 \cdot 5 \mu \mathrm{M} / \mathrm{kg}$./day. It will be noted that these figures, in general, are considerably higher than those obtained in normal children under the stress of a

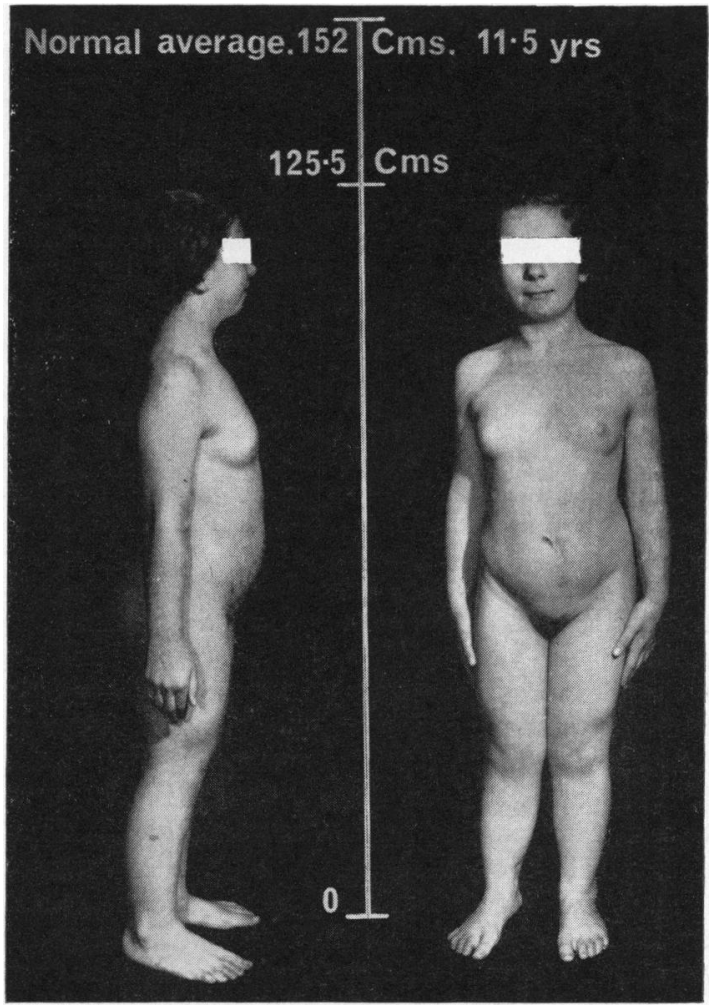

Fig. 2.-Appearance of patient at $11 \frac{1}{2}$ years.

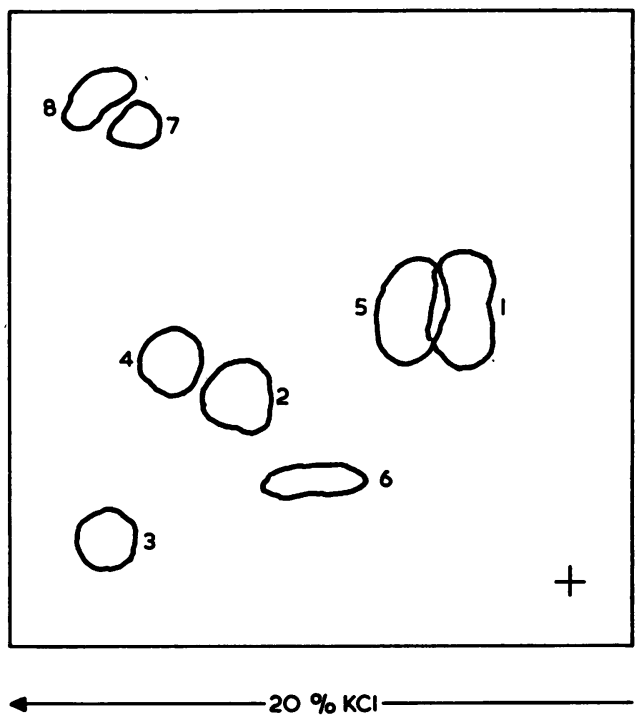

Fig. 3.-The chromatograms were viewed under ultraviolet light (253 mu). (1) Xanthurenic acid; (2) 3-hydroxykynurenine; (3) 3hydroxykynurenine sulphate; (4) kynurenine; (5) kynurenic acid; (6) $\beta-(8$ - xanthurenyl) - glucosiduronic acid; (7) acetyl-3hydroxykynurenine; (8) acetyl-kynurenine. 
TABLE 1

URINARY EXCRETION OF TRYPTOPHAN METABOLITES AFTER AN ORAL LOAD OF TRYPTOPHAN ( $\mu \mathrm{M}$ of substance/kg./24 hr.)

\begin{tabular}{|c|c|c|c|c|c|c|c|}
\hline Authors & Subjects & $\begin{array}{l}\text { Load Test } \\
\text { Tryptophan }\end{array}$ & Kynurenine & $\begin{array}{c}\text { Kynurenic } \\
\text { Acid }\end{array}$ & $\begin{array}{l}\text { 3-Hydroxy- } \\
\text { kynurenine }\end{array}$ & $\begin{array}{c}\text { 3-Hydroxy- } \\
\text { anthranilic } \\
\text { Acid }\end{array}$ & $\underset{\text { Acid }}{\text { Xanthurenic }}$ \\
\hline 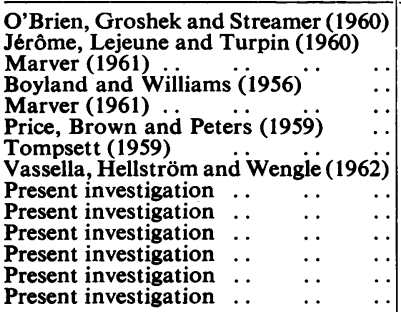 & $\begin{array}{l}25 \text { children } \\
20 \text { children } \\
9 \text { children } \\
9 \text { adults } \\
30 \text { adults } \\
29 \text { adults } \\
3 \text { adults } \\
22 \text { children } \\
6 \text { adults } \\
5 \text { children } \\
\text { Patient } \\
\text { Patient } \\
\text { Mother } \\
\text { Father }\end{array}$ & $\begin{array}{c}250 \mathrm{mg} . / \mathrm{kg} . \mathrm{DL}^{*} \\
30 \mathrm{mg} / \mathrm{kg} . \mathrm{L} \dagger \\
2 \mathrm{~g} . \mathrm{L} \\
10 \mathrm{~g} . \mathrm{DL} \\
2 \mathrm{~g} . \mathrm{L} \\
2 \mathrm{~g} . \mathrm{L} \\
5 \mathrm{~g} . \mathrm{L} \\
100 \mathrm{mg} \cdot / \mathbf{k g} . \mathrm{L} \\
5 \mathrm{~g} . \mathrm{L} \\
100 \mathrm{mg} \cdot / \mathbf{k g} . \mathrm{L} \\
\text { No load } \\
100 \mathrm{mg} . / \mathrm{kg} . \mathrm{L} \\
5 \mathrm{~g} . \mathrm{L} \\
5 \mathrm{~g} . \mathrm{L}\end{array}$ & $\begin{array}{c}1 \cdot 3 \\
3-4 \\
2 \cdot 3 \\
0 \cdot 7 \\
0 \cdot 4 \\
0 \cdot 3-0 \cdot 4 \\
9 \cdot 6 \\
\\
3 \cdot 5 \\
50\end{array}$ & $\begin{array}{l}0 \cdot 9 \\
3 \cdot 3 \\
5 \cdot 5\end{array}$ & $\begin{array}{c}0 \cdot 6-0 \cdot 9 \\
0 \cdot 5 \\
0 \cdot 5 \\
0 \cdot 7 \\
1 \cdot 8 \\
\\
25 \\
47\end{array}$ & $\begin{array}{c}0.5 \\
1 \cdot 5-2 \cdot 0 \\
3 \cdot 6\end{array}$ & $\begin{array}{c}7 \cdot 4 \\
1 \cdot 0 \\
\\
\\
0 \cdot 6 \\
0 \cdot 75 \\
1 \cdot 5-6 \cdot 0 \\
1 \cdot 0-1 \cdot 5 \\
21 \\
200 \\
18 \\
7 \cdot 1\end{array}$ \\
\hline
\end{tabular}

tryptophan load (Table 1). When the patient was given an oral load of $2.5 \mathrm{~g}$. of L-tryptophan she excreted the same metabolites as before together with the acetylated derivatives of kynurenine and 3-hydroxykynurenine in much the same way as the normal person, except that the quantities excreted were much higher and the higher concentration was maintained over a longer period. For instance (Fig. 4) the excretion of xanthurenic acid amounted to $200 \mu \mathrm{M} / \mathrm{kg}$./day, which alone would account for about $40 \%$ of the ingested tryptophan. We were unable to detect any excretion of anthranilic acid or of 3-hydroxyanthranilic acid. In a further trial the patient was given intramuscular injections of pyridoxin $(50 \mathrm{mg}$.) both 24 hours before and immediately before the oral dose of tryptophan. This was done in view of the possibility that the absorption of pyridoxin by the oral route might be impaired in this patient. The excretion pattern of the tryptophan metabolites was practically the same as before except that the excretion of xanthurenic acid was somewhat lower, but this was offset by a higher excretion of kynurenic acid. There was also an additional dark blue fluorescent spot, so far unidentified, in a position on the paper chromatogram just to the left of and just above the kynurenine. Further paper chromatographic studies have shown that the excretion of 3-indolyl acetic acid has remained within normal limits throughout. Also Mr. Maurice Bell (Manchester Royal Infirmary) found no significant increase in the excretion of 5-hydroxytryptamine or 5-hydroxyindoleacetic acid in the urine following the tryptophan loads.

The parents of the patient were also given oral tryptophan load tests. Her mother showed an exaggerated response, and this is illustrated in Fig. 4. Her excretion of xanthurenic acid $(18 \mu \mathrm{M} / \mathrm{kg}$./day) was at least three to four times higher than that obtained from other adults that we have tested. Her father, on the other hand, responded more normally, but his xanthurenic acid excretion was near the upper limit of our normal range.

\section{Discussion}

Tryptophan may be metabolized in several ways, but the major pathway in the human, as well as in many other species, is through a series of enzyme-catalysed reactions leading to the formation of nicotinic acid or nicotinamide (Dalgliesh, 1960). This pathway can be illustrated as follows:

$$
\begin{aligned}
& \text { Tryptophan } \\
& \text { Formylkynurenine } \\
& \text { Kynurenic acid } \leftarrow \text { Kynurenine } \rightarrow \text { Anthranilic acid } \\
& \text { Xanthurenic acid } \leftarrow \text { 3-hydroxykynurenine } \rightarrow \text { 3-hydroxy- } \\
& \text { anthranilic acid } \\
& \downarrow \\
& \text { Nicotinic acid }
\end{aligned}
$$

Since the patient accumulates large quantities of kynurenine, 3-hydroxykynurenine and xanthurenic acid but shows no sign of excreting anthranilic acid or 3-hydroxyanthranilic acid we can assume that she has a metabolic block at a point just preceding the formation of these latter compounds. This step requires the presence of kynureninase together with pyridoxal phosphate as co-enzyme. We have tried to explain our findings first on the basis of a deficiency of pyridoxal phosphate and secondly as the result of an absence or a greatly diminished production of kynureninase. A deficiency of pyridoxyl phosphate might arise as a result of: (1) an inadequate intake of pyridoxin; (2) decreased availability of pyridoxal phosphate due to lack of kinase; (3) increased 
production of 4-pyridoxic acid producing a situation of increased pyridoxin need, i.e. pyridoxin dependency.

The lack of response of pyridoxin by mouth or by injection to change the urine chromatographic findings rules out a pyridoxin deficiency. The clinical picture in no way suggests vitamin $\mathbf{B}_{6}$ dependency, there being no fits and a normal EEG pattern. The fact that there was no improvement at all following intensive $\mathbf{B}_{6}$ treatment suggests that a decreased availability of pyridoxal phosphate is unlikely: some would be produced by the kinase pathway unless the block was complete and one might then expect an increased production of pyridoxamine and pyridoxamine phosphate from which the co-enzyme would be produced by transamination. Hence we feel justified in suggesting an

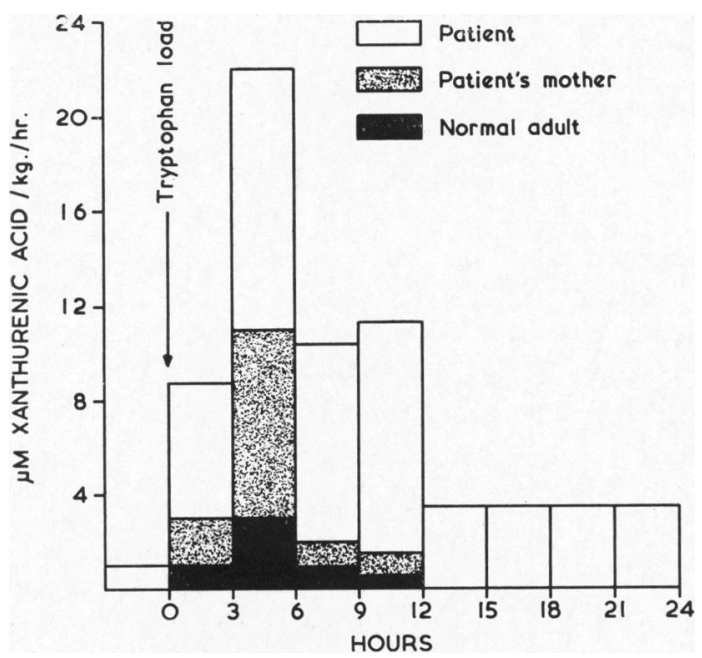

FIG. 4.-The urinary excretion of xanthurenic acid after taking an oral load of tryptophan.

absence or greatly diminished production of kynureninase.

A complete lack of kynureninase would lead to a block in the pathway of tryptophan to nicotinic acid so that in this case tryptophan can no longer be considered as a source of this vitamin. Thus the patient would be entirely dependent on the nicotinic acid or nicotinamide, as such, present in the diet. For the first six months this consisted largely of cows' milk which yielded only $0 \cdot 3-0.5 \mathrm{mg}$. of nicotinic acid per day (Lawrence, Herrington, and Maynard, 1946), whereas the recommended intake is put at 4-6 mg. per day at this age (Food and Nutrition Board, National Research Council, Washington). It is, therefore, likely that the child was suffering from an acute deficiency of nicotinic acid at this time. We know that she was given 'abidec' from the age of 6 months onwards and thus received about $5 \mathrm{mg}$. per day in addition to that derived from the diet. This may have modified the clinical picture to some extent as certainly most of her acute symptoms arose during the first six months. Last summer, when the 'abidec' was stopped temporarily and only ascorbic acid was continued, she developed a sensitivity to sunlight, that disappeared when nicotinamide was restored to the diet. On another occasion when on a 'no added vitamins, vegetable-free' diet and neomycin, severe diarrhoea supervened within 48 hours. We had hoped to demonstrate that the N-methyl-nicotinamide excretion was low or absent in the urine when the child was deprived of nicotinamide, but Dr. Kodicek, who had agreed to make the assay, found that the intense fluorescence of the excreted tryptophan metabolites in the urine invalidated his method.

It is interesting to note that this block in the major pathway of tryptophan metabolism does not apparently stimulate an increased use of the other alternative routes of utilization either to 5-hydroxytryptamine or to indolylpyruvic or indolylacetic acids or to indican. It is relevant to comment that in another metabolic disease involving tryptophan (Hartnup's disease), which also exhibits clinical signs of a nicotinic acid deficiency, the metabolic fault causes an increased excretion of indican. This is considered to be a secondary effect due to an abnormal intestinal bacterial flora modified by an unusually high concentration of tryptophan present in the gut. This, in turn, has been explained, in these cases, as being due to a diminished absorption of tryptophan through the gut wall (Milne, Crawford, Girão and Loughridge, 1960). This wasteful utilization of tryptophan results in smaller amounts of this amino acid being available for the formation of nicotinic acid.

The bloody diarrhoea of infancy, the stomatitis and also the mental retardation (Gregory, 1955) could be the results of a nicotinic acid deficiency, but it is difficult to explain the severe haemolytic anaemia on this basis. Could this be the result of the absence of one or more missing intermediate metabolites including 3-hydroxyanthranilic acid, and others on the pathway between 3-hydroxykynurenine and nicotinic acid? On the other hand, it might be that the abnormally high concentrations of 3-hydroxykynurenine and xanthurenic acid in the tissues cause toxic effects particularly during the early period of active growth.

In common with other disorders of amino acid 
metabolism, such as phenylketonuria and maple syrup urine disease, one would expect this new syndrome to be hereditary. Unfortunately there are no other sibs, but the parents agreed to have tryptophan load tests. The mother excreted three to four times the normal amount of xanthurenic acid and the levels of excretion of kynurenine and 3hydroxykynurenine and their acetylated derivatives remained high over a longer period than is usual. However, the father, under the same conditions, behaved normally although his excretion of xanthurenic acid was in the upper limit of our normal range.

\section{Summary}

A patient is described who excreted large amounts of kynurenine, 3-hydroxykynurenine and xanthurenic acid in the urine.

It is postulated that the increased excretion of these substances arises due to the absence in the tissues of the enzyme kynureninase which, in turn, leads to a metabolic block in the pathway of tryptophan to nicotinic acid.

In these conditions tryptophan can no longer be regarded as a source of nicotinic acid, and it is believed that the patient suffered from a deficiency of this vitamin when she was on an all milk diet.

The hereditary nature of the condition is discussed.

We wish to acknowledge the financial help received from the Manchester University Rag Fund, the Manchester Regional Hospital Board, the Lawson Tait Trust and the Friends of the Royal Manchester Children's Hospital.

\section{REFERENCES}

Bessey, O. A., Adam, D. J. D. and Hansen, A. E. (1957). Intake of vitamin $B_{6}$ and infantile convulsions: $A$ first approximation of requirements of pyridoxin in infants. Pediatrics, 20, 33.

Boyland, E. and Williams, D. C. (1956). The metabolism of tryptophan 2. The metabolism of tryptophan in patients suffering from cancer of the bladder. Biochem. J., 64, 578.

Charconnet-Harding, F., Dalgliesh, C. E. and Neuberger, A. (1953). The relation between riboflavin and tryptophan metabolism, studied in the rat. ibid., 53, 513.

Coursin, D. B. (1961). Present status of vitamin $\mathbf{B}_{6}$ metabolism. Amer. J. clin. Nutr., 9, 304.

Dalgliesh, C. E. (1956). Two-dimensional paper chromatography of urinary indoles and related substances. Biochem. J., 64, 481.

- (1960). Biosynthesis of niacin and pyridoxine. In Symposium XI: Vitamin Metabolism. 4th Int. Congr. of Biochem., Vienna, 1958, Vol. 11, p. 32. Pergamon Press, London.

- Knox, W. E. and Neuberger, A. (1951). Intermediary metabolism of tryptophan. Nature (Lond.), 168, 20.

Dent, C. E. (1951). Paper chromatography and medicine. In Recent Advances in Clinical Pathology, 2nd ed., ed. S. C. Dyke, p. 238. Churchill, London.
Gregory, I. (1955). Role of nicotinic acid (niacin) in mental health and disease. J. ment. Sci., 101, 85 .

Heidelberger, C., Abraham, E. P. and Leprovsky, S. (1949). Tryptophan metabolism II. Concerning the mechanism of the mammalian conversion of tryptophan into nicotinic acid. J. biol. Chem., 179, 151.

Hunt, A. D., Stokes, J., McCrory, W. W. and Stroud, H. H. (1954). Pyridoxine dependency: Report of a case of intractable convulsions in an infant controlled by pyridoxine. Pediatrics, 13, 140.

Jérôme, H., Lejeune, J. and Turpin, R. (1960). Étude de l'excrétion urinaire de certains métabolites du tryptophane chez les enfants mongoliens. C.R. Acad. Sci. (Paris), 251, 474.

Johnston, C. C. and Mason, M. (1962). Tryptophan metabolism: Formation of $\beta$-(8-Xanthurenyl)-glucosiduronic acid in the rat and in rat kidney slices. J. biol. Chem., 237, 29.

Knapp, A. (1962). Uber eine erbliche Störung im Tryptophanstoffwechsel in Abhängigkeit von der Vitamin $\mathbf{B}_{6}$-Zufuhr. $Z$. menschl. Vererb.-u Konstit.-Lehre, 36, 258.

Kotake, Y. and Nakayama, T. (1941). Úber die Anthranilsaürebildung aus Kynurenin durch Organsaft. Hoppe-Seylers $Z$. physiol. Chem., $270,76$.

- and Tani, S. (1953). Studies on xanthurenic acid III. Xanthurenic acid in the urine of a diabetic patient. J. Biochem. (Tokyo), 40, 295.

Lawrence, J. M., Herrington, B. L. and Maynard, L. A. (1946). The nicotinic acid, biotin, and pentothenic acid content of cows' milk. J. Nutr., 32, 73.

Marver, H. S. (1961). Studies on tryptophan metabolism. I. Urinary tryptophan metabolites in hypoplastic anemias and other hematologic disorders. J. Lab. clin. Med., 58, 425.

Milne, M. D., Crawford, M. A., Girão, C. B. and Loughridge, L. (1960). The excretion of indolylacetic acid and related indolic acids in man and the rat. Clin. Sci., 19, 165.

Molony, C. J. and Parmelee, A. H. (1954). Convulsions in young infants as a result of pyridoxine (Vitamin $\mathrm{B}_{6}$ ) deficiency. J.Amer. med. Ass., 154, 405.

Musajo, L., Benassi, C. A. and Parpajola, A. (1956). Excretion and isolation of kynurenine and 3-hydroxykynurenine from human pathological urine. Clin. chim. Acta, 1, 229.

O'Brien, D., Groshek, A. P. and Streamer, C. W. (1960). Abnormalities of tryptophan metabolism in children with mongolism. Amer. J. Dis. Child., 100, 540.

— and Jensen, C. B. (1963). Pyridoxine dependency in two mentally retarded subjects. Clin. Sci., 24, 179.

Price, J. M., Brown, R. R. and Peters, H. A. (1959). Tryptophan metabolism in porphyria, schizophrenia, and a variety of neurologic and psychiatric diseases. Neurology (Minneap.), 9, 456.

Rosen, F., Huff, J. W. and Perlzweig, W. A. (1946). The effect of tryptophan on the synthesis of nicotinic acid in the rat. J.biol. Chem., 163, 343.

Scriver, C. R. (1960). Vitamin $\mathbf{B}_{6}$-dependency and infantile convulsions. Pediatrics, 26, 62.

Sigler, M. H., Sheehy, T. W., Santini, R. and Rubini, M. E. (1962). Xanthurenic aciduria in tropical sprue. Amer. J. med. Sci., 244, 197.

Smith, I. (1958). Chromatographic Techniques. Clinical and Biochemical Applications, p. 114. Heinemann, London. (1960). Chromatographic and Electrophoretic Techniques. Vol. 2, Zone Electrophoresis, p. 158. Heinemann, London.

Tompsett, S. L. (1959). The determination in urine of some metabolites of tryptophan-kynurenine, anthranilic acid and 3-hydroxyanthranilic acid-and reference to the presence of o-aminophenol in urine. Clin. Chim. Acta, 4, 411.

Vassella, F., Hellström, B. and Wengle, B. (1962). Urinary excretion of tryptophan metabolites in the healthy infant. Pediatrics, 30, 585.

Wachstein, M. and Gudaitis, A. (1952). Detection of Vitamin $\mathbf{B}_{6}$ deficiency. Utilization of an improved method for rapid determination of xanthurenic acid in urine. Amer.J. clin. Path., 22, 652 . 